\title{
New and Unexpected Demographic Challenges to Educational Leadership in Nigeria
}

\author{
Felicia Ofoegbu \\ Nkechi Obiweluozor \\ Department of Educational Studies and Management, Faculty of Education, \\ University of Benin, Benin City
}

\author{
Doi:10.5901/jesr.2015.v5n1p39
}

\section{Abstract}

The result of our study shows that educational leadership and management, from time to time, experiences new and unexpected demographic challenges which include wanton violence, migration, and disproportionate rise in student population, regional wars and kidnapping. Such situations affect leadership and the management of education with regard to enrolment of students, their attendance and retention. The study was a survey and used as cohort all the 90 post primary schools in the seven Local Government Councils in Plateau State. Two instruments; a questionnaire and the attendance registers were used for the study. Against the background provided by the findings a number of recommendations were made to achieve equitable management in such situations. The result strongly recommends for leadership a democratic, visionary leader actively involved and committed to change based on collective agreement, belief and values of everyone concerned with quality education.

Keywords: New, Unexpected, Demographic, Challenges

\section{Introduction}

The concept of educational leadership as an important factor in ensuring school effectiveness and in securing wide improvement in the school system has been identified by several authors including Newman and Wenlage (1995), Harris (2006) and Ofoegbu, Clark and Osagie (2013). In these studies educational leadership is widely acknowledged as vital to capacity building and change inspired progress.

Even though recent empirical studies have in no small measure identified the pivotal role of educational leadership in ensuring the effectiveness of schools (Harris, 2006) one indisputable fact in the progress of education is that education leaders face series of challenges in the management of education. Most of the educational institutions in Nigeria are faced with serious financial handicap, inadequate classrooms for teaching and learning, lack of relevant facilities and equipment and with these are other related problems namely,

- tremendous increase in students' population,

- the cosmopolitan nature of the students,

- the uncertain quality of teachers,

- economic and societal pressures,

- severe poverty with high prevalence of killer diseases such as malaria and HIVIAIDs,

- global and technological changes

- Perverse practices including corruption and nepotism.

In the face of these challenges educational leadership appears wanting in the management of schools. It was observed of recent that educational managers were not resistant to new and unexpected challenges which though temporary in effect, might bring in their wake sudden and unexpected demographic changes both in the internal and external environment of the school system. Walker and Carr-Stewart (2006) refer to such challenges as "dramatic changes". These challenges are much debated and well acknowledged among Governments and the society. Contemporary interpretations of new and unexpected challenges cut across several areas of interest to school leadership;

- insecurity of life and property

- lack of enrolment poor attendance on the part of children and schools for fear of or violence and kidnapping,

- the effects of urbanization

- erosion threatened external environment 
- Sudden movement of people within and across borders in response to acts of terrorism and regional wars.

\section{Related Literature Review}

There are various leadership theories since the process of leadership is not static but dynamic (Cole, 1990). However in this study educational leadership is seen as a relational concept and therefore it is hinged on a distributive theory of leadership practice which builds on the activity theory that offers a way of understanding how leaders go about their work, why they do and think the way they do and how they address the relations between structure and human agency (Moller, 2004).

Distributive leadership also referred to as "team" (Carson, Tesluk and Marrone, 2007) and "shared" leadership (Mintzberg, 2006) implies that in decision making the leader is obliged, not at his pleasure, to involve designated persons who by their knowledge and experience are experts in certain areas of administration and together arrive at equitable decision in keeping with the goals of the organization.

Indeed, distributive leadership challenges the traditional concept of leadership which assumes that leadership should reside in a single individual. This is the result of the observation that the pressure and stress that people in leadership face is enormous and that as Ofoegbu, Clark \& Osagie (2013) pointed out, it was highly unlikely that one single person could provide the necessary leadership, knowledge, skills, talents and abilities on all issues. While school managers are undoubtedly important sources of leadership in schools the current waves of violence and terrorism, regional wars and sudden movement of people within and across boundaries are compelling reasons to adopt collaborative and shared practices that contribute to organizational knowledge and improvement (Spillane, 2006).

Educational leadership expresses the process of influencing and uniting people around key values towards desirable ends (Wassererberg, 2000). Suffice it to say that the type of leadership is concerned with the manner and way the principals, as school managers, apply themselves to create the school climates that enable staff and students to be productive and creative.

There is also growing evidence to associate educational leadership with organizational development and positive change (Macbeath, 2005; Harris and Muis, 2004, Murphy and Datnow, 2005; Sergiovanni, 2001). However, Harris (2006) affirms that educational leadership is susceptible to new challenges. Indeed the rapid and unprecedented changes around the world impose the necessity on educational leadership to consider itself as a professional driving force and mediator for the development of the school towards learning effectiveness ((Bush, 2005). This is even more so now that schools are increasing in complexity and witnessing unremitting demographic changes (Bush, 2005). According to Harber and Davis (1997), Clark and Ofoegbu (2014) war related events do impact on educational leadership and management; such conflicts often resulted in loss of lives and student absenteeism and attrition and also closure of schools.

The Department of Education in South Africa (2002) holds the view that educational leadership may be hampered by violence and crime but claims that some of the worse crimes lie outside the school. They argue that the most important factor contributing to safe schools, low levels of violence and attrition is good school management. Also schools with clear norms and expectations, fair procedures, and schools that involve all members of the community (parents, students, educators and community services) are less likely to experience high levels of violence than those where such systems and relationships are not in place.

\subsection{Statement of the problem}

Recently, contemporary issues such as sudden movement of people within and across borders in response to terrorism, insecurity of life and property, unwarranted killings and climate change are increasingly being identified as realities of the Nigerian education system. Recently it was reported in the Vanguard Newspaper (2014) that well over 10, 000 school age children did not have access to education. Consequently educational leadership has become a complex concept which has generated widespread interest in the management of schools. Leadership in education must continually look for ways to attract and keep students happy, healthy and productive while coping with "stress-related" roles and "burnout" traits.

It has been observed that virtually all studies in the field of leadership have focused their attention on leadership styles, traits and behaviour. Hence even though several leadership studies have been carried out very little is known about which form of sudden demographic change affect leadership practices. Also very little is known about the ways in which school managers enact their roles and interact with teachers and students when unexpected crisis occur within 
and outside the school environment. Neither do we know according to Harris (2006) how leadership practices are shared, negotiated and constructed in schools to facilitate organizational effectiveness. In view of the seemingly new and sudden (dramatic) challenges to educational leadership the study seeks to find out whether there is any relationship between "dramatic" demographic challenges and educational leadership. It is also to find if there is any relationship between new unexpected challenges and the management of education in the context of access to school, attendance, retention, absenteeism, classroom population and quality of teaching.

\subsection{Research Questions:}

To guide the study the following research questions were raised:

1) What are the new and unexpected significant demographic challenges to educational leadership?

2) To what extent do new and unexpected challenges affect enrolment in schools?

3) Is there any relationship between new and unexpected demographic challenges and educational leadership?

4) Is there any relationship between new and unexpected demographic challenges and educational management with regard to access to school, attendance, retention, absenteeism, classroom population and quality of teaching?

\subsection{Hypotheses:}

Question one and two were answered while questions three and four were hypothesized

Ho1. There will be no significant relation between new and unexpected demographic challenges and educational leadership.

Ho2. There will be no significant effect of unexpected demographic challenges on educational management with regard to access to school, attendance, retention, absenteeism, classroom population and quality of teaching.

\section{Methodology}

The study was a survey. The population of the study comprised all the 90 public secondary schools located in the seven Local Government Councils in Plateau State. The State was purposely selected; because it shares geographic borders with the State where the "Boko Haram" insurgency is significantly pronounced. All the ninety schools which translates to (90) principals were used for the study, hence there was no sampling.

\subsection{Research Instrument}

Two research instruments were use to collect data for the study. The first was a questionnaire entitled "Educational Leadership and New Unexpected Challenges Questionnaire" (ELNUQ) directed at principals. It was made up of two sections; Section A was used to collect demographic data on the respondents (principals) while Section B was used to find out the new and sudden demographic challenges and the impact of such challenges on educational leadership and other variables like students access to school. The second instrument was the classroom register from 2010 and 2014 school year. This was retrieved from the schools in order to find out the enrolment and the rate of attrition.

\section{Finding and Discussion}

Presented in Tables 1 to 4 are the findings of the study.

Research Question 1: what are the new and unexpected challenges of educational leadership? 
Table 1: Mean and Standard Deviation Summary of Principals' Perceived New and Unexpected Challenges in Nigerian Secondary Schools.

\begin{tabular}{|l|c|c|c|}
\hline New and unexpected challenges $\mathbf{( N = 9 6 )}$ & Mean & Deviation & Remark \\
\hline Regional wars & 19.79 & 3.79 & $\mathrm{~S}$ \\
Violence & 19.80 & 3.80 & $\mathrm{~S}$ \\
Instability of External and internal environment & 17.61 & 3.63 & $\mathrm{~S}$ \\
Economic and Social pressure & 17.86 & 3.27 & $\mathrm{~S}$ \\
Migration & 6.29 & 3.63 & $\mathrm{~S}$ \\
Kidnapping & 5.56 & 3.62 & $\mathrm{~S}$ \\
High education demand & 0.23 & 1.12 & $\mathrm{NS}$ \\
\hline
\end{tabular}

$\mathrm{S}=$ Significant

Table 1 shows the new and unexpected challenges as perceived by school managers. The findings reveal that Regional wars (mean: 19.79), Violence (Mean: 19.80), instability of external and internal environment

(Mean: 17.61), Economic and Social Pressures (Mean: 17.86), Kidnapping (Mean: 8.68) respectively and Migration (Mean: 6.29) are some "dramatic" challenges to which educational leadership is particularly susceptible. The analysis in table 1 shows that the respondents were in strong agreement as concerns the impact of new and unexpected challenges to educational leadership and management. State?

Research Question 2: To what extent do new and unexpected challenges affect school Enrolment in Plateau

Table 2: New and Unexpected Demographic Challenges and School enrolment

\begin{tabular}{|c|c|c|c|c|c|c|}
\hline Local Government Council & Number of schools & Enrolment 2011/2012 & Enrolment 2012/2013 & Attrition & Rate of Attrition & Remark \\
\hline A & 13 & 4,900 & 2234 & 2666 & $46 \%$ & Very high \\
\hline B & 30 & 8691 & 4246 & 4445 & $49 \%$ & Very high \\
\hline C & 18 & 5032 & 1863 & 3169 & $37 \%$ & Very high \\
\hline D & 07 & 2077 & 686 & 1391 & $33 \%$ & Very high \\
\hline E & 12 & 3725 & 701 & 3014 & $19 \%$ & high \\
\hline F & 05 & 1671 & 318 & 1353 & $19 \%$ & high \\
\hline G & 05 & 2160 & 554 & 1606 & $26 \%$ & Very high \\
\hline
\end{tabular}

Source: Field work

Table 2 shows that the attrition rate in the seven Local Government Councils in the Cohort State between 2011/2012 and $2012 / 2013$ school years ranges from $19 \%$ to $49 \%$ which is very high.

Hypotheses 1: There will be no significant relationship between new and unexpected demographic challenges and educational leadership.

Table 3: Pearson "r" relationship between dramatic challenges and educational leadership

\begin{tabular}{|l|c|c|c|c|c|c|}
\hline Variables & No. & Mean & SD & Pearson "r" & Significant Valve & Remark \\
\hline New an unexpected challenges & 90 & 2.87 & 0.50 & \multirow{2}{*}{0.762} & \multirow{2}{*}{0.017} & \multirow{2}{*}{ Significant } \\
\hline Educational Leadership & 90 & 2.67 & 0.58 & & & \\
\hline
\end{tabular}

The analysis of Pearson Correlation "r" is shown in Table 2. The result shows that the calculated "r" of 0.762 is greater than the critical $p$ - valve of 0.017 at 0.05 level of significance. Therefore the null hypothesis which states that there will be no significant relationship between new and unexpected demographic challenges and educational leadership is rejected. New and unexpected demographic challenges have serious impact on educational leadership and management.

Ho2There will be no significant effect of unexpected demographic challenges on educational management with regard to access to school, attendance, retention, absenteeism, classroom population and quality of teaching. 
Table 4: Mean and Standard Deviation of Principals Responses on the effect of unexpected demographic challenges on Educational Management

\begin{tabular}{|l|c|c|c|c|}
\hline Factors & Mean & SD & f-value & Remark \\
\hline High students rate of attrition & 3.80 & 0.71 & $66.0^{* \star}$ & Significant \\
\hline Increase in irregular students school attendance & 3.60 & 0.56 & $51.5^{\star \star}$ & Significant \\
\hline High migration of students & 3.20 & 0.51 & $28.6^{* \star}$ & Significant \\
\hline Low students retention in school & 3.65 & 0.69 & $51.8^{\star \star}$ & Significant \\
\hline Low student enrolment & 3.76 & 0.72 & $62.7^{* \star}$ & Significant \\
\hline Difficulty in the management of schools in an unstable internal environment. & 3.50 & 0.55 & $44.8^{\star \star}$ & Significant \\
\hline Low students Population due to unstable school internal and external environments. & 3.00 & 0.61 & $42.9^{\star \star}$ & Significant \\
\hline Low quality of teaching and learning. & 2.91 & 0.70 & $16.4^{* \star}$ & Significant \\
\hline
\end{tabular}

Source: Field Work

The result in Table 4 shows that new and unexpected demographic challenges significantly affect educational management. All the areas of school management selected for the study are highly affected by such challenges. The Means, Standard Deviation and the calculated f-value indicate that the principals did not greatly vary in their responses to the effect of such challenges. It is concluded that sudden demographic challenges affect school management.

\section{Discussion}

All aspects of schooling including its locational environment are in the ambit on the rights of the child; its protection, survival and educational development are at the centre of such responsibilities. The study confirms that educational leadership is susceptible to new and sudden challenges as noted by Harris (2006). Indeed in many countries including Nigeria, everyday presages some bizarre occurrences like killings, kidnapping, and violence are challenges which pose physical threats to educational management (table 1); war-related events are not conducive to effective leadership functions.

According to the finding educational leadership in Nigeria periodically meets new and unexpected challenges. The finding is in consonance with that of Harber and Davis (1997) which states that principals are often faced with maintaining a semblance of order in an increasingly hostile, unpredictable and conflict laden environment. School management in the $21^{\text {st }}$ century is a highly tasking challenge.

A situation where the school is unsafe, where the external environment records a high incidence of violence and killings, does contribute significantly to absenteeism, low retention of students and a high rate of attrition, situations which are in conflict with the objectives of management.

The principals identified some aspects of their functions that are adversely affected by such demographic challenges (Table 4). Millions of Nigerians already live in fear (Guardian Newspaper, June 2013) and there is no gainsaying the fact that children may not readily attend school effectively if they are weakened by insecurity of life (Table 2). The implication of new and unexpected demographic challenges is that the leaders may experience confusion, even frustration in their attempt to respond adequately to these pressures.

\section{Conclusion and Recommendation}

The study concludes that new and unexpected demographic challenges affect educational leadership in Nigeria. The findings suggest that in such situations the leadership should focus more on the practices that would enhance school development. In schools where principals know and clarify their goals, exhibit self confidence, have courage to take decisions in the midst of strong dramatic challenges, the principal and teacher collaborative efforts are strongly recommended; no leader knows it all. (Sebring \& Bryk, 2000; Hopkins, Harris et al, 2011).

Therefore the following recommendations are made

1) To survive and grow in a dwindling economy with regional wars, violence, crumbling facilities, increasing number of special need students and varying demands by stakeholders (Barko \& Ramadan, 2002; Walker and Carr-Stewart, 2006) there is need for the development of effective leadership programme. At the heart of this is the encouragement of the ability on the part of leaders to work cooperatively with other members of the organization and the community.

2) If educational leadership is serious about running and sustaining effective schools there is need to set clear 
goals and expectations, fair procedural processes and involve members of the community and major stake holders (parents, teachers and learners) in decision making.

3) Principals may not achieve quality and effectiveness by acting alone (Caldwell (2004) or by operating a structured central control built around themselves with subordinates answerable only to them. The success of the school depends on the capacity of the leadership to "join networks to share knowledge, address problems and pool resources".

4) The study strongly recommends that more leadership training and motivation are required if principals are to carry out their responsibility effectively and successfully. Meanwhile there is need to adopt the team-task response for change which states that

"Managers can no longer simply wait for instruction or decision from government. The pace of change and the need to be adaptable and responsive to local circumstances requires that managers develop new skills and styles of working. They must be capable of providing leadership for teams and be able to interact with communities both inside and outside the school (Dept. of Education, 1996:14)".

5) Government on its part should endeavour to forestall and quell such incidences by ensuring that people are gainfully employed as it is said 'an idle mind is the devils work shop'.

\section{References}

Bush, Tony (2005) Leadership and Management Development in Education. SAGE.

Bako, S. and Ramadan, S.J. (2002) The 20th century Principal: The perspective of Government in The 21 ${ }^{\text {st }}$ Century Principal in Nigeria Akpa, Owoicho (Ed). All Nigerian Conference of Principals of Secondary Schools, Plateau State Chapter.

Cadwell, B (2004) Re-Imagining the Self Managing School iNET Pamphlet, Special Schools Trust, London

Carson, J. B, Tesluk, P. E \& Marrone, J. A (2007) "shared leadership in teams; an investigation of antecedent conditions and performance" Academy of Management Journal (50), $1217-1231$

Clark, A.O and Ofoegbu, F. I (2014) Effects of Demographic Factors on Educational Leadership and Management Journal of Educational Studies and Management 2 (1) $176-190$.

Cole, N (1990) Conceptions of Educational Management, Educational Research. 19, 2 - 7.

Davis, L and Harber C (1997) School Management and Effectiveness in Developing Countries: The Post bureaucratic School. London: Cassel

Day, C., Harris, A, Hadfield, M., Tolley, H and Beresford, J. (2000) Leading Schools in Times of Change. Buckingham, UK; Open University Press.

Department of Education (1996) South African Schools Act, Pretoria, South Africa

Department of Education (2002) signposts for safe schools, Tirisano. A resource book from South Africa Police Service and Department of Education

Guardian News Paper (2013). Millions of Nigerians are living in hunger. Pg 25, June, Thursday17

Harris, A. (2003) Distributed Leadership and School Improvement: Leading or Misleading? Educational Management, Administration and Leadership 32(1)11-24.

Harris A (2006) Opening up the "Black Box" of Leadership Practice: Taking a Distributed Leadership perspective. Journal of the Commonwealth Council for Educational Administration and Management (CCEAM) 34 (2) 37-45.

Harris, A and Muijs. D (2004) Improving Schools through Teacher Leadership. London, OU Press

Leithwood, K and Levin, B (2005) Assessing School Leader and Leadership Programme, Effects on Pupil Learning, Department of Education and Skills Research Report. rr662.

MacBeath, J (2005) Leadership as Distributed :A matter of Practice. School Leadership and Management. 26 (5)

Mintzberg, H (2006). The Leadership Debate With Henry Mintzberg; Communityship Is the Answer". Financial Times, http.//www/ft.com

Moller, J (2007) Improving School Leadership. Country background report for Norway, OECD Depart of Teacher Education and School Development, University of Oslo.

Murphy, J and Datnow, A (2003) Leadership Lessons For Comprehensive School Reforms. Thousand Oaks.

Newman, F and Wehlage, G (1995) Successful School Restructuring. Alexandria, V.A: ASCD

Ofoegbu, F, Clark, A \& Osagie, R (2013) Leadership Theories and Practice: Charting the Part for Improved Nigerian Schools, Journal of the Commonwealth Council for Educational Administration and Management (CCEAM) 41 (2) 67 - 76

Sergiovanni, T (2001) Leadership: What's In It for Schools? London Rutledge Falmer.

Shields, C (2006) Creating Spaces for Value - Based Conversations: The Role Of Leaders In The 21st Century. Journal of the Commonwealth Council for Educational Administration and Management (CCEAM). 34 (2) 62-81

Spillane, J.P. (2006) Distributed Leadership San Francisco Jossey Boss

Walker Keith and Carr-Stewart Sheila (2006) Beginning Principals: Experience and Images of Success. Journal of the Commonwealth Council for Educational Administration and Management (CCEAM) 34 (3) 17-36.

Wasserberg, M (2000) Creating The Vision And Making It Happen, in H. Tomlison, H. Gunter and P. Smith (Eds.) Living Headship London: Paul Chapman Publishing. 